\title{
Non-operative treatment approach for blunt splenic injury: is grade the unique criterion?
}

\author{
Künt dalak yaralanmalarında ameliyatsız tedavi: \\ Derecelendirme tek kriter midir?
}

\author{
Bülent KOCA, ${ }^{1}$ Koray TOPGÜL, ${ }^{2}$ Saim Savaş YÜRÜKER, ${ }^{1}$ \\ Hamza ÇINAR, ${ }^{1}$ Bekir KURU ${ }^{1}$
}

\section{BACKGROUND}

We aimed to investigate the results of a non-operative approach to blunt spleen injury to re-evaluate the importance of injury grade.

\section{METHODS}

Thirty-one blunt splenic trauma cases subjected to nonoperative treatment were evaluated retrospectively. The patients were classified into two groups as isolated spleen trauma (ST) group and multi-trauma (MT) group. The hospitalization and blood replacement needs, success of non-operative follow-up, and post-traumatic complications were compared between the two groups. The patients were evaluated via follow-up abdominal ultrasonography (US) and computerized tomography (CT). The results were evaluated with regard to post-splenic trauma complications.

\section{RESULTS}

According to the organ injury scale of the American Association for the Surgery of Trauma, $25.8 \%$ were grade-1, $32.2 \%$ grade- 2 , $29 \%$ grade- 3 , and $12.9 \%$ grade- 4 injuries. It was observed that the transfusion amount was directly proportional to the injury grade. All patients with grade- 4 injury and 14 patients with MT were treated successfully with the non-operative method. Splenic pseudoaneurysm developed in one patient in the MT group. One patient was diagnosed with late splenic rupture.

\section{CONCLUSION}

Hemodynamic stability is the most important criterion for the indication of non-operative treatment. However, in wellselected cases, patients with grade 4 splenic traumas and those with extra-splenic injuries could also be treated successfully with the non-operative method.

Key Words: Blunt splenic trauma; complication; injury grade; nonoperative management.

\begin{abstract}
AMAÇ
Bu çalışmada, künt dalak yaralanmasına ameliyatsız yaklaşım sonuçlarını irdelemeyi, yaralanma derecesinin önemini yeniden değerlendirmeyi amaçladık.
\end{abstract}

\section{GEREÇ VE YÖNTEM}

Cerrahi dışı yöntemle tedavi edilen 31 künt dalak yaralanmalı olgu geriye dönük olarak incelendi. Hastalar izole dalak travması (DT) grubu ve çoklu travma (ÇT) grubu olmak üzere iki gruba ayrıldı. İki grup arasında yatış süresi, kan replasmanı ihtiyacı, ameliyatsız izlem başarısı ve travma sonrası komplikasyonlar karşılaştırıldı. Hastalar kontrol karın ultrasonografisi (US) ve bilgisayarlı tomografi (BT) ile değerlendirildi. Elde edilen sonuçlar postsplenik travma komplikasyonları ile ilgili olarak değerlendirildi.

\section{BULGULAR}

Amerikan Travma Cerrahisi Derneği organ hasarı skoruna göre, olguların $\% 25,8$ 'inde derece $1, \% 32,2$ 'sinde derece 2 , $\% 29$ 'unda derece 3 ve \%12,9'unda derece 4 yaralanma vardi. Transfüzyon miktarının yaralanma derecesi ile doğrudan orantılı olduğu görüldü. Ortalama yatış süresi MT grubunda daha uzundu. Derece 4 yaralanma ve çoklu travmalı olan 14 hasta ile tüm hastalar ameliyatsız yöntem ile başarıyla tedavi edildi. MT grubunda bir hastada splenik psödoanevrizma gelişti. Bir hastada geç dalak rüptürü tanısı kondu.

\section{SONUÇ}

Hemodinamik stabilite konservatif tedavi endikasyonu için en önemli ölçüttür. Ancak, iyi seçilmiş olgularda 4. derece dalak yaralanması olan ve dalak dışı yaralanmalar da ameliyatsız tedavi ile başarılı bir şekilde tedavi edilebilir.

Anahtar Sözcükler: Künt dalak travması; komplikasyon; yaralanma derecelendirmesi; ameliyatsız tedavi.

\footnotetext{
${ }^{1}$ Department of General Surgery, Ondokuz Mayis University Faculty of Medicine, Samsun;

${ }^{2}$ Department of General Surgery, Medical Park Samsun Hospital, Samsun, Turkey.
}

${ }^{1}$ Ondokuz Mayıs Üniversitesi Tıp Fakültesi,

Genel Cerrahi Anabilim Dalı, Samsun; ${ }^{2}$ Medical Park Samsun Hastanesi, Genel Cerrahi Bölümü, Samsun. 
In recent years, a non-operative approach for blunt spleen injuries has become the first choice in hemodynamically stable patients with grades 1,2 and 3 injuries. Preservation of the spleen decreases the risk of early surgical complications such as adjacent organ injury, wound infection, pancreatitis, pleural effusion, and atelectasia as well as late splenectomy complications such as sepsis, serious infections and thromboembolic events.$^{[1,2]}$ Generally, splenectomy is an easy operation for trauma surgeons, while preservation of the spleen is a more laborious procedure. On the other hand, preserving the spleen is important in terms of early- and late-period outcomes.

For many years, we have used a non-operative treatment and follow-up approach in blunt splenic trauma patients in our clinic. In the present study, we investigated the complications of splenic trauma, the incidence of which increases as non-operative treatment becomes more widespread, and present the results of the non-operative approach to blunt spleen injury in our patients. In addition, we aimed to compare with the treatment results of multi-organ trauma patients and isolated splenic injury patients who were treated by the non-operative method. Concurrently, we revisited the algorithms related to this issue.

\section{MATERIALS AND METHODS}

This study was conducted in Department of General Surgery Ondokuz Mayis University Faculty of Medicine between January 2008 and December 2010. Thirty-one blunt splenic trauma cases subjected to non-operative treatment among the 45 blunt splenic trauma cases were evaluated retrospectively. Spleen injuries were classified according to the Abbreviated Injury Scale (AIS). The patients were classified into two groups as "isolated spleen trauma" (ST group) or "multi-trauma" (MT group). The hospitalization and blood replacement needs, success of non-operative follow-up, and post-traumatic complications were compared between the two groups. After their discharge, the patients were evaluated via follow-up abdominal ultrasonography (US) and computerized tomography $(\mathrm{CT})$. Interviews with the patients were conducted, and information about their current health status was obtained. The results were evaluated with regard to post-splenic trauma complications.

\section{Statistical analysis}

The statistical analysis was performed (with variance analysis and chi-square tests) by using the software Office 2007 Statistical Package for the Social Sciences (SPSS) 13. A p value $<0.05$ was considered statistically significant.

\section{RESULTS}

The median age of the 31 patients included in this study, who had splenic injury due to blunt abdominal trauma and were subjected to treatment with non-operative methods, was 46 (range, 18-79) years. Eighteen patients $(58 \%)$ were male and $13(42 \%)$ were female. Isolated splenic injury was observed in 17 patients $(55 \%)$ and intra-abdominal multiple organ injury in 14 patients $(45 \%)$. Hepatic injury was observed in 7 patients $(22.5 \%)$, surrenal injury in 4 patients $(12.9 \%)$, renal injury in 2 patients $(6.4 \%)$, and hematoma in the small intestinal mesothelium in 1 patient (3.2\%). Thirteen patients $(41.9 \%)$ had rib fracture at the left thorax and 5 patients $(16.1 \%)$ had hemothorax. Nine $(29 \%)$ of the patients were injured by in-vehicle traffic accident, $16(51.6 \%)$ by falling from height, $4(12.9 \%)$ by stroke, and $2(6.4 \%)$ by out-of-vehicle accident. According to the organ injury scale of the American Association for the Surgery of Trauma, 8 patients $(25.8 \%)$ had grade- 1,10 patients $(32.2 \%)$ grade-2, 9 patients (29\%) grade-3, and 4 patients $(12.9 \%)$ grade-4 injuries (ST group: 5 patients grade-1, 6 patients grade-2, 4 patients grade-3, 2 patients grade-4, and MT group: 3 patients grade- 1,4 patients grade- 2,5 patients grade- 3 , 2 patients grade-4). Thirty-five units of erythrocyte suspension were given to the 31 patients. We observed that 8 units of blood transfusion were given to the 17 patients with isolated spleen injury (ST) and 27 units of blood transfusion to the 14 MT patients. 1.1 units of erythrocyte suspension per patient were given. 0.27 units of erythrocyte suspension per patient were given to patients with grade 1-2 injury versus 2.3 units per patient given to patients with grade 3-4 injury. It was observed that the transfusion amount was directly proportional to the injury grade. No blood transfusion was given to the group of 17 patients with grade 1-2 ST, while 1.33 blood transfusions per patient were given on average to the group consisting of those with grade 3-4 injury. The average blood transfusion per patient was 1.92 units in the MT group, with 0.71 units in the group with grade 1-2 and 2.66 units in the group with grade 3-4 injuries (Table 1).

The amount of the blood transfusion was significantly higher in the grade 1-2 group with MT as compared with the ST group $(p=0.048)$. In the grade 3-4 group, the amount of blood transfusion was higher in the MT group; however, the difference showed borderline significance $(p=0.051)$. It was observed that most of the patients in the MT group subjected to transfusion were those with hepatic injury and hemothorax. During the follow-up period, the hemodynamics of one patient (in the grade-3 ST group) was impaired on the 5th day; his hematocrit was 21 in spite of administration of 3 units of erythrocyte suspension. On the follow-up CT, the subcapsular splenic hematoma identified during the first CT was seen to have ruptured and led to disseminated hemoperitoneum, although it was not present on the first CT. Diagnosis of late 
Table 1. The duration of hospitalization and replacement quantities of the two groups

\begin{tabular}{cccc}
\hline & Isolated group & Multi-trauma group & $p$ \\
\hline Length of stay & & & \\
Grade 1-2 & 3.18 & 3.85 & 0.084 \\
Grade 3-4 & 7 & 9.57 & 0.234 \\
Replacement & 0 & & \\
Grade 1-2 & 1.33 & 0.71 & 0.048 \\
Grade 3-4 & & 2.66 & 0.051 \\
\hline
\end{tabular}

Chi-square test.

splenic rupture was established and splenectomy was The patient was discharged after nine days of hospitalization. Thirty patients (97\%) were discharged after having been treated successfully with a non-operative approach. The average hospitalization period was 5.51 days (3.44 days in grade 1-2 and 8.38 days in grade $3-4)$. The average hospitalization period was 4.52 days in the ST group (3.18 days in grade 1-2 and 7 days in grade 3-4) and 6.7 days in the MT group (Table 1). The hospitalization period was longer in the MT group; however, no significant differences were found $(p=0.084$ for grade $1-2$ and $p=0.234$ for grade $3-4)$. All of the 4 patients with grade-4 injury (Fig. 1a) and 14 patients with MT were treated successfully with the non-operative method. In 1 patient in the MT group (grade-3 injury), splenic pseudoaneurysm appeared on the 7lh day follow-up abdominal CT (Fig. 1b), and the patient underwent angiographic embolectomy in the department of radiology (Fig. 2). The patient was discharged after 10 days of hospitalization. He is in good health after his discharge (for 14 months). Ten of the 31 patients included in the study were over 55 years old (32.2\%). Four of the 10 patients over 55 years old were in the MT group. One patient was 76 years old and had grade- 4 MT. All of the patients in this group were treated with a non-operative method. None of the patients had post-traumatic complications. No significant statistical differences in the hospitalization period $(p=0.21)$ or amount of blood transfusions $(p=0.18)$ were found in the MT group.

The median follow-up period of patients included in the study was 28 months. In the evaluations for the post-traumatic splenic complications, one patient was diagnosed with late splenic rupture, and one patient with pseudoaneurysm; however, pseudocyst was not observed. The incidence of complication was $6.45 \%$ in the patients with splenic trauma during the non-operative treatment.

One of two patients with post-splenic trauma complication was from the ST group and the other was from the MT group. No differences were found between the two groups in terms of the post-traumatic complications.

\section{DISCUSSION}

After the liver, the spleen is the second most commonly injured intra-abdominal organ in blunt abdominal trauma, with an incidence of $32 \%{ }^{[3]}$ The most common causes for the blunt spleen injury, as in our
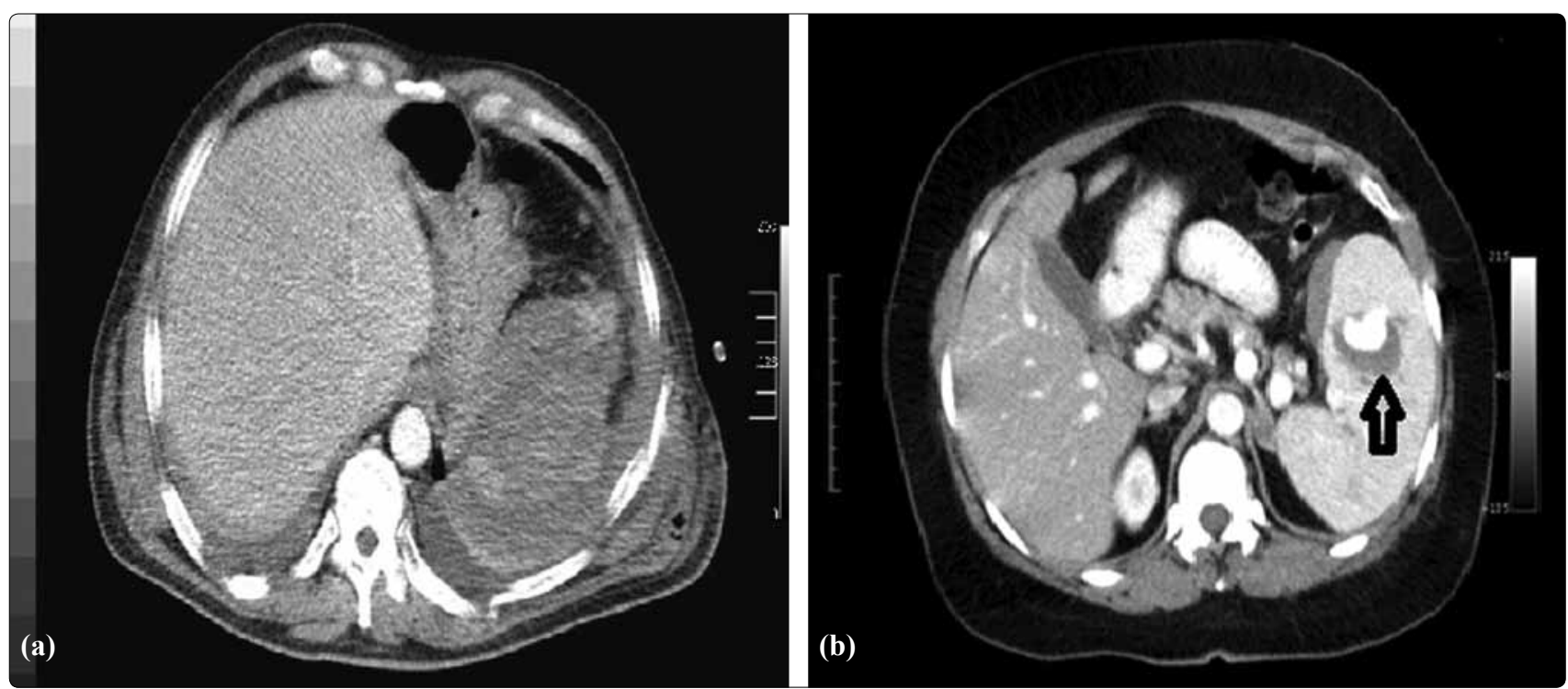

Fig. 1. (a) Grade-4 spleen injury. (b) Image of pseudoaneurysm in CT. 


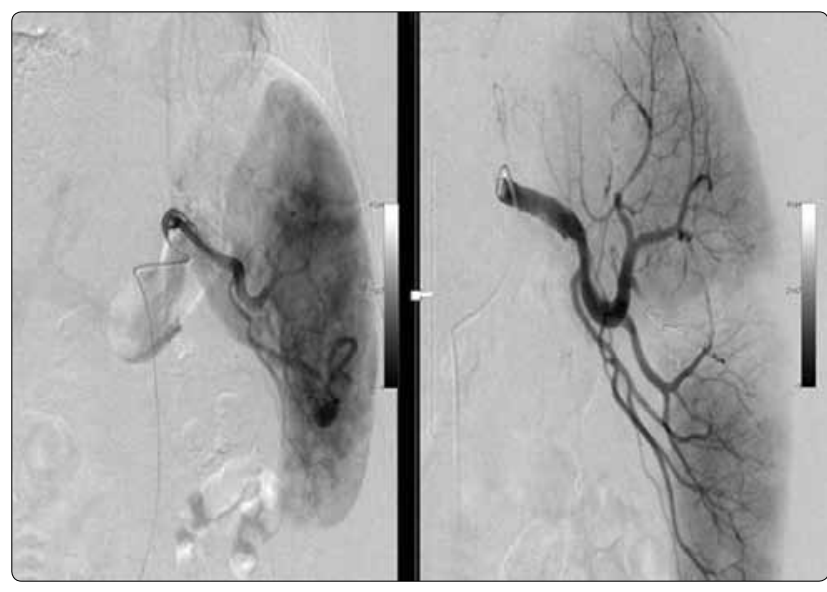

Fig. 2. Angiographic image of the pseudoaneurysm before and after embolization.

study, are "in-vehicle" accidents, "out of vehicle" accidents, falls from height, and stroke. In patients with splenic injury, splenectomy had been the only treatment method for years. In the 1970s, when spleen functions and the post-splenectomy complications were understood more clearly, the spleen-preserving surgical methods became the preferred approach. The most recent development in traumatic splenic injuries is the non-operative treatment. It has been reported that $60 \%$ of blunt spleen injuries may be treated successfully with non-operative treatment. ${ }^{[4]}$ In our series, the incidence of non-operative treatment was $66.6 \%$.

It is known that the spleen has several important functions, including immunology, coagulation, storage, filtration, ${ }^{[5]}$ iron metabolism, and wound healing. The spleen takes part in alternative complement system activation, tuftsin production, $\mathrm{T}$ and $\mathrm{B}$ lymphocyte maturation, and iron and factor 8 storage ${ }^{[6]}$ Mortality is $50-70 \%$ in post-splenectomy sepsis, even when optimal antibiotic therapy and supportive care are provided ${ }^{[7]}$ In the early post-splenectomy period, complications including hemorrhage, adjacent organ injury, wound infection, pancreatitis, and pleural effusion may occur. Patients treated with a non-operative method are protected against all of these complications.

Therefore, at present, the non-operative method is the first choice in suitable patients. ${ }^{[8]}$ At this point, patient selection becomes important in decision-making for the non-operative method of treatment. Patients with grade 3-4 injury, above 55 years of age, who received 4 units of blood transfusion during the first 24 hours, with head traumas, and with intraabdominal MTs were excluded from the non-operative treatment group in many studies. ${ }^{[9,10]}$ In our study, patients with grade- 4 injury, MT and above 55 years of age were treated successfully with non-operative treatment. Regarding patient selection for non-operative treatment, we consider that it is not logical to impose strict limitations except regarding hemodynamic status and comorbid factors. Hemodynamic stability is the most important criterion for non-operative treatment indication. ${ }^{[11]}$ The radiological grade of the injury is an important criterion; however, in well-selected cases, grade- 4 spleen traumas and extra-splenic injuries may be treated successfully with a non-operative approach as well as in grade 1-2-3 injuries.

Ultrasonography (US), CT and diagnostic peritoneal lavage (DPL) may be used as a diagnostic method for splenic injury. US can identify hemoperitoneum with $90-93 \%$ sensitivity; however, its sensitivity for determining the splenic trauma classification is lower. ${ }^{[12]}$ Furthermore, it is not adequate for detecting small intestine, colon, mesothelium, and retroperitoneal injuries. ${ }^{[13]}$ The risk of false- positives in patients with hematuria and pelvic and vertebral fracture is high. ${ }^{[14]}$ Since it is a fast and easy-to-use method for patients with impaired hemodynamics, it may be the first choice for diagnosis. In most trauma centers, US is used to monitor low-grade splenic injuries. ${ }^{[15]} \mathrm{CT}$ is the gold standard for the diagnosis of spleen injury following a blunt abdominal trauma, especially in patients with stable hemodynamics ${ }^{[8]} \mathrm{CT}$ gives clear information about other peritoneal and retroperitoneal organs as well as the amount of intraabdominal hemorrhage, and in addition, may reveal pseudoaneurysms and arteriovenous fistulas in the spleen. ${ }^{[16]}$ In our clinic, we prefer to use CT as the first choice for evaluating blunt abdominal traumas in hemodynamically stable patients. DPL is a diagnostic technique that can be used for diagnosis of blunt abdominal traumas, and it can identify hemoperitoneum with 97\% sensitivity. ${ }^{[17]}$ However, it cannot give information about the source of the hemorrhage. If the spleen trauma is identified by US or CT, we do not perform DPL in our clinic.

In our clinic, we prefer to use CT as the first choice in the diagnosis stage in hemodynamically stable patients, and we classify the cases according to the AIS. The grade 1-2-3-4 patients with stable hemodynamics and without head trauma are treated with non-operative methods, irrespective of their ages. In patients with grade 1-2 and isolated spleen injuries, we prefer US as the first choice during the follow-up process, since it is cheap and easy to perform. In patients with grade 3-4 isolated spleen injuries and in all grades of MT patients, CT is used during the follow-up.

The last entity we encountered in consequence of the application of non-operative treatment is postsplenic trauma complications. Late splenic rupture, splenic pseudocyst, arteriovenous fistula, and splenic pseudoaneurysms are the complications observed late after spleen traumas. Late splenic rupture has an incidence of $1 \%$ and mortality rate of $5-15 \%$ and occurs 
4-8 days after the trauma. ${ }^{[18]}$ The mechanism causing the rupture is subcapsular hematoma, pseudocyst or rupture of the pseudoaneurysm. ${ }^{[19]}$ Arteriovenous fistula arises after blunt abdominal trauma, as a result of which the vein in the trauma area opens to the existing splenic artery aneurysm or to the post-traumatic pseudoaneurysm. ${ }^{[20]}$ Splenectomy may be used for its treatment. Angiography is a strong alternative to surgery, since it has a low-risk potential and lower complication risk in comparison with splenectomy. ${ }^{[21]}$ Pain, fever, and hemorrhage may be observed after angioembolization.
At the conclusion of the present study, we revisited and presented the algorithm of the conservative treatment of splenic injuries according to our clinical experiences, as shown in Figure 3.

In conclusion, hemodynamic stability is the most important criterion for the indication of non-operative treatment in blunt splenic trauma. ${ }^{[14,21]}$ The radiological grade of the injury is an important criterion. However, in well-selected cases, patients over 55 years, with grade-4 splenic traumas and with extra-splenic injuries could also be treated successfully with the

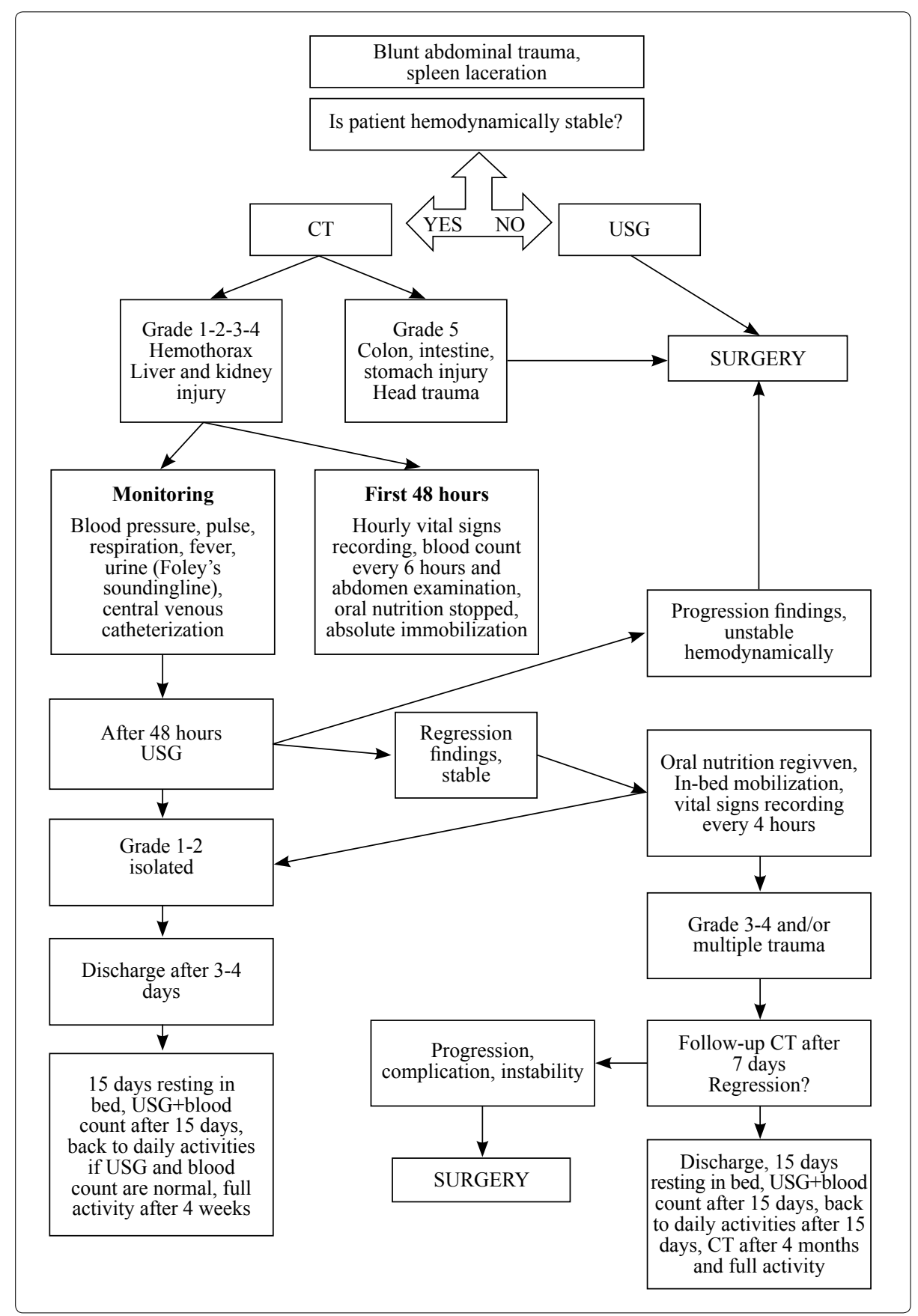

Fig. 3. The algorithm that is applied in our clinic for blunt spleen trauma. 
non-operative approach, in addition to those with grade 1-2-3 injuries.

We believe that the spleen is an invaluable organ, and as such, surgeons should strive to protect it by reason of its many vital functions.

Conflict-of-interest issues regarding the authorship or article: None declared.

\section{REFERENCES}

1. Mohren M, Markmann I, Dworschak U, Franke A, Maas C, Mewes S, et al. Thromboembolic complications after splenectomy for hematologic diseases. Am J Hematol 2004;76:143-7.

2. Durakbasa CU, Timur C, Sehiralti V, Mutus M, Tosyali N, Yoruk A. Pediatric splenectomy for hematological diseases: outcome analysis. Pediatr Surg Int 2006;22:635-9.

3. Smith J, Caldwell E, D'Amours S, Jalaludin B, Sugrue M. Abdominal trauma: a disease in evolution. ANZ J Surg 2005;75:790-4.

4. Cales RH, Trunkey DD. Preventable trauma deaths. A review of trauma care systems development. JAMA 1985;254:1059-63.

5. Hansen K, Singer DB. Asplenic-hyposplenic overwhelming sepsis: postsplenectomy sepsis revisited. Pediatr Dev Pathol 2001;4:105-21.

6. Altamura M, Caradonna L, Amati L, Pellegrino NM, Urgesi G, Miniello S. Splenectomy and sepsis: the role of the spleen in the immune-mediated bacterial clearance. Immunopharmacol Immunotoxicol 2001;23:153-61.

7. Holdsworth RJ, Irving AD, Cuschieri A. Postsplenectomy sepsis and its mortality rate: actual versus perceived risks. $\mathrm{Br}$ J Surg 1991;78:1031-8.

8. Cadeddu M, Garnett A, Al-Anezi K, Farrokhyar F. Management of spleen injuries in the adult trauma population: a tenyear experience. Can J Surg 2006;49:386-90.

9. Knudson MM, Maull KI. Nonoperative management of solid organ injuries. Past, present, and future. Surg Clin North Am 1999;79:1357-71.

10. Patcher HL, Liang HG, Hofstetter SR. Liver and biliary tract trauma. In: Mattox KL, Felliciano DV, Moore EE, editors. Trauma. 4th ed. New York: Mc Graw Hill; 2000. p. 633-82.

11. Heuer M, Taeger G, Kaiser GM, Nast-Kolb D, Kühne CA, Ruchholtz S, et al. No further incidence of sepsis after splenectomy for severe trauma: a multi-institutional experience of The trauma registry of the DGU with 1,630 patients. Eur J Med Res 2010;15:258-65.

12. van der Vlies $\mathrm{CH}$, van Delden OM, Punt BJ, Ponsen KJ, Reekers JA, Goslings JC. Literature review of the role of ultrasound, computed tomography, and transcatheter arterial embolization for the treatment of traumatic splenic injuries. Cardiovasc Intervent Radiol 2010;33:1079-87.

13. Schnüriger B, Kilz J, Inderbitzin D, Schafer M, Kickuth $\mathrm{R}$, Luginbühl $\mathrm{M}$, et al. The accuracy of FAST in relation to grade of solid organ injuries: a retrospective analysis of 226 trauma patients with liver or splenic lesion. BMC Med Imaging 2009;9:3.

14. Miller MT, Pasquale MD, Bromberg WJ, Wasser TE, Cox J. Not so FAST. J Trauma 2003;54:52-60.

15. Boulanger BR, McLellan BA, Brenneman FD, Wherrett L, Rizoli SB, Culhane J, et al. Emergent abdominal sonography as a screening test in a new diagnostic algorithm for blunt trauma. J Trauma 1996;40:867-74.

16. Miller LA, Shanmuganathan K. Multidetector CT evaluation of abdominal trauma. Radiol Clin North Am 2005;43:107995.

17. Forsythe RM, Harbrecht BG, Peitzman AB. Blunt splenic trauma. Scand J Surg 2006;95:146-51.

18. Kluger Y, Paul DB, Raves JJ, Fonda M, Young JC, Townsend $\mathrm{RN}$, et al. Delayed rupture of the spleen-myths, facts, and their importance: case reports and literature review. J Trauma 1994;36:568-71.

19. Freiwald S. Late-presenting complications after splenic trauma. Perm J 2010;14:41-4.

20. Maloo MK, Burrows PE, Shamberger RC. Traumatic splenic arteriovenous fistula: splenic conservation by embolization. J Trauma 1999;47:173-5.

21. Salis A, Pais SO, Vennos A, Scalea T. Superselective embolization of a traumatic intrasplenic arteriovenous fistula. J Trauma 1999;46:186-8. 